\title{
Palacios y conventos a finales de la Edad Media: la reina Catalina de Lancaster y Santa María la Real de Nieva
}

\author{
Sonia CABAllero Escamilla \\ Dpto. Historia del Arte \\ Universidad de Granada \\ caballero.sonia@gmail.com
}

\begin{abstract}
RESUMEN
La existencia de un palacio real en un convento, en este caso dominico, responde a una tipología de gran arraigo en la Península Ibérica. Dedicamos el presente artículo a su estudio e interpretación, centrándonos en el convento de Santa María la Real de Nieva, patrocinado por la reina Catalina de Lancaster. Finalmente, planteamos un análisis sobre la función y recepción de las imágenes distribuidas en la portada de la iglesia en relación con el contexto histórico y social, demostrando ciertos visos de antijudaísmo en el tratamiento de algunos temas.
\end{abstract}

Palabras clave: palacio real, convento, Catalina de Lancaster, Santa María la Real de Nieva.

\section{ABSTRACT}

The existence of a royal palace in convent, in this case Dominican, answers to a typology of great rooting in the Iberian Peninsula. We dedicate the present article to the study and interpretation of this typology, centring on the convent of Santa Maria la Real de Nieva, supported by the queen Catalina de Lancaster. Finally, we raise an analysis on the function and receipt of the images distributed in the door of the church in relation with the historical and social context, demonstrating certain appearances of antiJudaism in the treatment of some topics.

Keywords: royal palace, convent, Catalina de Lancaster, Santa María la Real de Nieva.

La necesidad de vivir en constante comunicación con la divinidad durante los siglos medievales trajo consigo la creación de estructuras arquitectónicas que facilitaran la proximidad entre la residencia real o nobiliaria y el templo. Así, en la mayoría de las iglesias del prerrománico asturiano ${ }^{1}$, su carácter áulico propició la existencia de tribunas que servían de asiento regio durante las ceremonias litúrgicas y que estaban comunicadas mediante un paso elevado con el palacio; la presencia de tribunas en el templo destinadas a miembros de la realeza forma parte de la tradición hispánica ya desde la Alta Edad Media, como es el caso de las iglesias de San Julián de los Prados, San Miguel de Lillo o San Salvador de Valdediós, por

1 I.G. BANGO TORVISO, "La vieja liturgia hispana y la interpretación funcional del templo prerrománico”, J.I. DE LA IGLESIA DUARTE (coord.), VII Semana de Estudios Medievales (Nájera, 29 de julio al 2 de agosto de 1996), Nájera, 1997, pp. 61-120. 
citar algunos ejemplos; su gran aceptación en la Península Ibérica hará que se convierta en una fórmula habitual también durante la época bajomedieval.

Las estancias regias asociadas a iglesias y conventos son una modalidad de gran arraigo en la Península Ibérica sobre la que llamó la atención Fernando Chueca Goitia en su clásico estudio Casas Reales en Conventos y Monasterios españoles ${ }^{2}$; desde que el célebre arquitecto e historiador centrara su atención en aquellos edificios más sobresalientes de la arquitectura española, la nómina de casos ha aumentado en los últimos años, poniéndose así de manifiesto que nos encontramos ante una tipología de gran aceptación por parte de los reyes hispánicos y, por extensión, de los nobles; en uno de esos ejemplos nos centraremos en las próximas páginas.

\section{Orígenes del convento de Santa María la Real de Nieva}

Santa María la Real de Nieva es una pequeña localidad ubicada en los límites de la provincia de Segovia. En la Edad Media se situaba entre los sexmos de la Trinidad y Santa Olalla y se sabe que mantuvo varios pleitos con la ciudad de Segovia al estar situada en la Tierra de Segovia con una jurisdicción especial ${ }^{3}$.

Su propio apelativo denuncia una vinculación con la monarquía, pues es sabido que esta población nació bajo el amparo y protección de los reyes castellanos a fines del s. XIV. Este hecho se tradujo en la concesión de ciertos privilegios que favorecieron su crecimiento, haciendo de este convento dominico una de las fundaciones más importantes de la Edad Media hispana.

La fundación de este insigne edificio está respaldada por un personaje real, la reina Catalina de Lancaster, tal y como da cuenta su advocación real. Nieta de Pedro I de Castilla por parte materna llegó a ser regente de Castilla cuando murió su marido Enrique III y durante la minoría de edad del heredero Juan II. Al igual que otras reinas hispanas actuó como asesora de su marido, influyendo de una manera determinante en la toma de algunas decisiones importantes. Pero lo que más nos interesa en este momento es su interés manifiesto por la actividad constructiva. Impulsó algunas reformas en el Alcázar de Segovia y en varios edificios religiosos, como el convento de dominicas de Mayorga o el que nos ocupa en el presente, el de Santa María la Real de Nieva ${ }^{4}$. Como vemos, las dos son fundaciones dominicas, orden por la que la reina debió de sentir especial devoción puesto que eligió el hábito de la misma como indumentaria fúnebre en la imagen que la inmortalizaría, la estatua yacente conservada en la Catedral de Toledo 5 . La protección a las órde-

F. CHUECA GOITIA, Casas reales en monasterios y conventos españoles, Madrid, 1982.

M. ASENJO GONZÁLEZ, Segovia. La ciudad y su Tierra a fines del medievo, Segovia, 1986, p. 107.

A. ECHEVARRÍA ARSUAGA, Catalina de Lancaster, Madrid, 2002.

Se conoce una estrecha correspondencia entre el rey Enrique III y su esposa Catalina de Lancaster y la priora del convento de Santo Domingo el Real de Toledo, Teresa de Ayala, y María de Castilla, monja también en el mismo monasterio y tía de la reina, vid. F.P. CAÑAS GÁLVEZ, "La itinerancia de la corte 
nes mendicantes, dominicos y franciscanos, por parte de los reyes hispanos en la Edad Media, demuestra hasta qué punto estas congregaciones religiosas atrajeron la atención de los más poderosos en materia espiritual, construyendo conventos, estableciendo en ellos sus enterramientos e, incluso, eligiendo su hábito como una forma de ingreso póstumo en la orden con la confianza de que les reportaría grandes beneficios espirituales. Esta atención privilegiada se tradujo en la fundación de conventos e, incluso, en las imágenes de los monarcas y otros personajes de alta alcurnia acompañados de los santos fundadores en obras destinadas a la devoción.

Pero, ¿cuál es el origen del Convento de Santa María la Real de Nieva? La advocación mariana nos lleva a relacionarlo con un culto local a la Virgen de Santa María de Nieva. Como ocurrió en multitud de templos medievales, su origen se vincula a la aparición milagrosa de la Virgen, a partir de la cual se construye un santuario para rendirle culto. Se trata de una manifestación más de la religiosidad popular, tan presente entre las gentes de la Edad Media, que traducía los dogmas profundos y complejos de la fe a un lenguaje sencillo y accesible, en el que las imágenes, los gestos o determinados ceremoniales -como las peregrinaciones y romerías-, les permitían aproximarse a su modo a las teorías que se propugnaban desde el seno de la Iglesia dentro de una concepción de la religiosidad más elitista 6 .

En esta ocasión, según la leyenda, fue en el año 1392 cuando un pastor de Nieva, de nombre Pedro de Buenaventura, encontró una imagen mariana enterrada que le pidió que levantara un santuario en su honor en ese mismo lugar. El humilde personaje contaría con el respaldo de la monarquía puesto que la misma reina Catalina asumió la labor de patronazgo ordenando levantar una iglesia bajo la advocación de Santa María de la Soterraña, en consonancia con otras imágenes encontradas en las mismas condiciones por la geografía peninsular. A raíz de este hecho, y una vez recibida la correspondiente bula otorgada por el Papa Clemente VII desde Avignon el 25 de febrero de 1393, comenzaron las obras. Al igual que en otras zonas, a la sombra del edificio religioso, surgió un núcleo poblacional tal y como ordenó el rey Enrique III en ese mismo año ${ }^{7}$.

La primera construcción debió de ser modesta puesto que fue dirigida por un grupo de seis capellanes y un prior elegido personalmente por la reina, Juan González. Sin embargo, no mucho después, en concreto en 1399, confió su dirección a

de Castilla durante la primera mitad del siglo XV", e-Spania [En ligne], 8 | (décembre 2009), mis en ligne le 10 janvier 2010. URL: http://e-spania.revues.org/. R. DÍEZ DEL CORRAL, Arquitectura y mecenazgo. La imagen de Toledo en el Renacimiento, Madrid, 1987. Sobre la indumentaria en los contextos fúnebres, M. NÚÑEZ RODRÍGUEZ, "La indumentaria como símbolo en la iconografía funeraria", Fragmentos, 10 (1987), pp. 72-84.

6 J. SÁNCHEZ HERRERO, "Desde el cristianismo sabio a la religiosidad popular en la Edad Media", Clío \& Crimen, 1 (2004), pp. 305-335.

7 M. LÓPEZ DÍEZ, Los Trastámara en Segovia. Juan Guas, maestro de obras reales, Segovia, 2006, p. 216. 
la Orden de Santo Domingo, poniendo a su cabeza al prior del Convento de Santa Cruz de Segovia fray Pedro de Sepúlveda. A partir de entonces, la orden dejaría su impronta no sólo en la organización estructural del edificio sino en su propia imagen visual puesto que las figuras de frailes dominicos, ejerciendo su labor de predicadores, pueblan varios capiteles del claustro. Por otro lado, y como veremos, la forma de culto propiciada y auspiciada por la orden dominica subyace en todo el programa iconográfico dispuesto en el conjunto, pues, como es sabido, las imágenes participan de la realidad social que las rodea ${ }^{8}$. Pero no sólo eso, la orden religiosa que regentaba el convento no ensombreció al poder terrenal que sustentaba el edificio, la monarquía. La protección dispensada por la Corona se dejó ver en detalles como las armas dispuestas en algunas zonas del claustro e, incluso, dos rostros regios en la portada de la iglesia. Desde Catalina de Lancaster, a la que podemos considerar la fundadora del convento, se sucedieron toda serie de favores y privilegios cedidos por diferentes monarcas, sobre todo mujeres. Así $\mathrm{D}^{\mathrm{a}}$ María, primera esposa del rey Juan II, fue protectora del convento, adquiriendo, por ello, el derecho de incorporar sus armas ${ }^{9}$.

La presencia de los monarcas en este convento no sólo se redujo a la protección económica sino que el lugar estratégico que ocupó, próximo a las villas de Arévalo, Medina del Campo, Segovia o Ávila, lo convirtió en paso obligado en los itinerarios que realizaban los monarcas de Castilla. Tanto es así que se aposentaron en alguna ocasión, lo que nos lleva a pensar en la posibilidad de que existiera un palacio en el mismo, que amplía la lista de residencias reales en edificios religiosos. En el intenso itinerario de los Reyes Católicos por la geografía castellana se conocen varias visitas al convento y no es de extrañar que pernoctaran en la residencia que ocuparon los monarcas anteriores ${ }^{10}$.

Conocemos la trayectoria del convento gracias a la epigrafía que nos ha legado un registro cronológico de la historia constructiva de la iglesia. De este modo, y si confiamos en la veracidad de los datos, podemos saber que las obras comenzaron en el año 1414 a cargo de la reina Catalina de Lancaster, tal y como reza en la inscripción sobre la pila del agua bendita acompañada del escudo de la reina:

8 J. BASCHET, "Inventiva y serialidad. Por una aproximación iconográfica ampliada", Relaciones, 77: XX (1999), p. 51.

9 Madrid, Archivo Histórico Nacional, Clero, Códices, 925 (Donación de Catalina de Lancaster, cédula 1-VII-1429) y Leg. 6.292 (Donación de D María). Véase F.M. DE LOS HOYOS, Registro documental, III, Valladolid, 1963. También el infante D. Alfonso confirmó algunos privilegios durante su reinado, M.S. MARTÍN POSTIGO, "Diez documentos de D. Alfonso como rey de Castilla a lugares y monasterios de la actual provincia de Segovia (1467-1468)", Homenaje a Fray Justo Pérez de Urbel, O. S. B., Abadía de Silos, 1976, pp. 483-512. Citado en M. LÓPEZ DÍEZ, op. cit., 2006, p. 217. Posteriormente Enrique IV otorga otros privilegios y los Reyes Católicos los confirman todos.

10 Sobre la itinerancia de los reyes en el S. XV, F.P. CAÑAS GÁLVEZ, op. cit., 2009; A. ROMEU DE ARMAS, Itinerario de los Reyes Católicos 1474-1516, Madrid, 1974, pp. 41 y 211-212. 
"Esta obra de estas capillas mandó hacer la muy noble, y excelente señora doña Catalina, reyna de Castilla y se comenzó día de San Ildefonso, año de mil quatrozientos y catorce, entonces era prior el honrado doctor fray Alonso de Amusco"11.

Acorde con el estilo que presenta la cabecera de la iglesia, la construcción del templo se puede datar en una fecha avanzada del s. XV, como se puede ver en la bóveda estrellada que cubre el crucero o en la misma portada principal de acceso, si bien, el interior fue bastante alterado en épocas posteriores, como dan cuenta las bóvedas barrocas de la nave central. A pesar de las reformas emprendidas posteriormente, los símbolos del patronazgo real se mantuvieron en las claves de las bóvedas, donde campean las armas regias y también en otras zonas del convento como el claustro.

\section{Un palacio real}

La intención de la reina Catalina de Lancaster fue construir una iglesia que albergara la imagen de Nuestra Señora de la Soterraña, venerada hasta ese momento en la ermita de Santa Ana. En 1399 se efectuó el traslado de la imagen al nuevo templo entregando la responsabilidad de custodiarla a la Orden de Predicadores. Pero el conjunto no sólo estuvo formado por la iglesia y el convento de los frailes sino que, siguiendo una fórmula que tiene su origen siglos atrás, la reina hizo construir una serie de aposentos regios en el lado sur destinados a acoger a los miembros de la familia real durante sus visitas al santuario.

El ingreso a las estancias reales se realiza a través de un vano apuntado sencillo sobre el que se sitúa una ventana enmarcada por un alfiz doble y en la que se constata la influencia mudéjar, como el friso de ladrillos situados en esquina y la combinación de mampostería y ladrillo atestiguan (fig. 1). Es posible que, al igual que en otras provincias cercanas como Ávila, trabajaran aquí mudéjares procedentes de Toledo. La parte correspondiente a las estancias reales se sitúa en el piso superior y presenta una galería de vanos geminados y trilobulados, con el lóbulo central ligeramente apuntado, mientras la parte inferior ofrece un aspecto

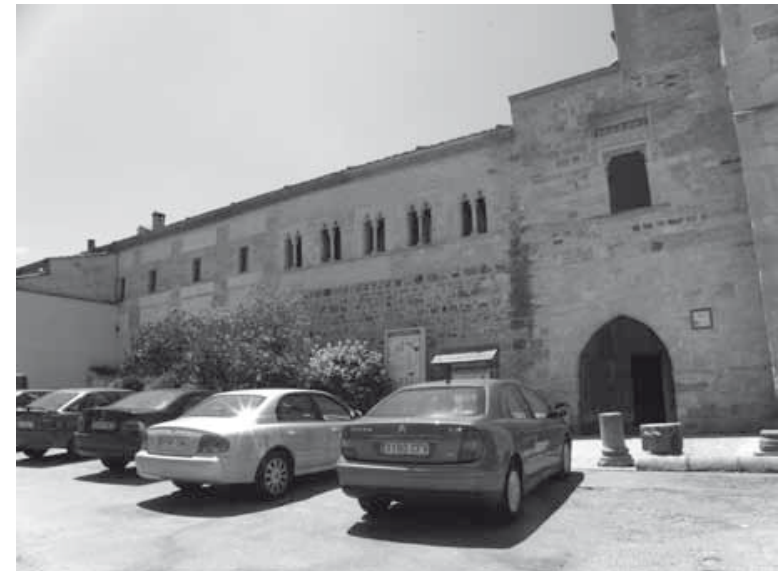

Fig. 1. Convento de Santa María la Real de Nieva, entrada al Palacio Real.

11 Inscripciones recogidas en M. LÓPEZ DÍEZ, op. cit., 2006, p. 218, nota 90. 
recio y macizo con un muro compuesto de mampostería e hiladas de ladrillo de un gusto muy toledano.

Una vez franqueado el arco se accede a un vestíbulo que desemboca en el claustro. Desde ese pasillo arranca una escalera, conocida como "escalera de la reina" 12 , que conduce a un rellano con tres puertas: la derecha comunica con una torre de aspecto defensivo desde la que se podía salvaguardar la entrada al palacio, quizás una estancia destinada al cuerpo de guardia; una pequeña puerta en el centro que puede enlazar con la tribuna desde la que los reyes asistían a las celebraciones religiosas y finalmente la izquierda que conduce a las habitaciones propiamente dichas, situadas en la galería superior este del claustro. Además, este palacio contaba con una entrada independiente a la iglesia como se puede constatar en la presencia de un arco apuntado realizado en ladrillo inmediatamente antes del acceso al claustro.

Existen noticias documentales sobre la expansión del monasterio hacia el sur con más estancias organizadas en torno a un segundo claustro:

“El segundo claustro es más pequeño con su jardín y pozo...hay en él algunas celdas y una magnífica en que se hospedan los religiosos provinciales cuando pasan por este territorio o vienen a visita...por este claustro bajo se entra en el refectorio..."13.

Nos encontramos ante una tradición que se remonta al menos a la monarquía asturiana por la que los reyes construían sus palacios junto a recintos sagrados, ya fueran monasterios o catedrales, con los que se pretendía dar respuesta a las necesidades de una corte itinerante a la vez que ofrecer una muestra pública de su devoción. Fernando Chueca Goitia, en su estudio sobre las casas reales en monasterios españoles, calificó esta tradición como "invariante castizo" de la arquitectura hispánica, que alcanzará su punto culminante en la cabecera de la Iglesia del Monasterio de El Escorial ${ }^{14}$. La condición piadosa y los intereses espirituales de los monarcas españoles exigieron, además, la construcción de un paso de comunicación entre la residencia palaciega y el templo que les procurara una vista privilegiada del altar para poder asistir a los oficios religiosos sin ser vistos. Se conocen muchos ejemplos de este tipo, algunos por las noticias documentales y otros conservados pero alterados al ser remodelados en siglos posteriores. Así ocurrió, por citar algunos casos, en San Isidoro de León, con la "cámara de Da Sancha", en la Catedral de Barcelona ${ }^{15}$, en la Cartuja de Valldecrist (Castellón) ${ }^{16}$, en San Jerónimo el Real,

${ }_{12}$ Así lo dice uno de los cronistas del Monasterio, que además vivió allí, el padre Yuraní. Citado por A. SÁNCHEZ SIERRA, El Monasterio de Santa María la Real de Nieva, Segovia, 1992, p. 129.

13 Ibidem, p. 128.

${ }_{14}$ F. CHUECA GOITIA, op. cit., 1982.

15 F. ESPAÑOL BERTRÁN, Els escenaris del Rei. Art i Monarquia a la Corona d'Aragó, Barcelona, 2001, pp. 16 y ss.

16 Vid. A. SERRA DESFILIS y M. MIQUEL JUAN, "La capilla de San Martín en la Cartuja de Valldecrist: construcción, devoción y magnificencia”, Ars Longa, 18 (2009), pp. 65-80. El rey Martín 
en Yuste o en El Escorial. Un ejemplo desconocido hasta no hace mucho es el de la Catedral de Toledo, donde la reina católica tuvo unas dependencias privadas con una tribuna abierta hacia la iglesia que fue remodelada en el s. XVIII pero que aún se conserva en la nave norte ${ }^{17}$. Este modelo no fue exclusivo de las personas de condición real sino que se hizo extensible también a los grandes linajes. Es el caso de una dama de confianza de la reina Isabel, $\mathrm{D}^{\mathrm{a}}$ María Dávila ${ }^{18}$, y su residencia en el Monasterio de Calabazanos, entre otros muchos, cuya lista se va ampliando cada vez más ${ }^{19}$.

En el caso que nos concierne en este momento, podemos rastrear noticias sobre la tribuna real en la iglesia de Santa María la Real de Nieva en los textos de los cronistas, como el siguiente de Pedro Fernández Monjaraz:

“...acomodada casa para su habitación tenían también sus majestades desde la suya un pasadizo por donde salir a la Capilla Mayor a un balcón..., en que asistían a los Oficios que los religiosos celebraban..."20.

Aún es visible el arco que comunicaba el templo con las estancias regias pero pasa desapercibido debido a las reformas emprendidas, del que aún se conservan dos arcos sepulcrales en la Capilla Mayor. Uno de ellos, el del lado de la epístola, es el correspondiente a la reina Blanca de Navarra, casada con el rey Juan II de Navarra ${ }^{21}$ que fue sobrino del rey Enrique III de Trastámara, uno de los fundadores del Convento de Santa María de Nieva.

I y su esposa María de Luna dispusieron de unas estancias comunicadas con la capilla de San Martín a través de un pasadizo que conducía a las dos tribunas reales. Agradecemos a los autores que nos proporcionaran el artículo y sus sugerencias durante las IV Jornadas de Arte Medieval en la Universidad Complutense.

17 F. MARÍAS y F. PEREDA, "La Casa de la Reina Isabel la Católica en la Catedral de Toledo: pasos y miradas", Goya, 319-320 (2007), pp. 214-230.

18 S. CABALLERO ESCAMILLA "María Dávila, nobleza y clausura: una mujer excepcional entregada al arte", Patrimonio, 39 (2009), pp. 51-58; "Semblanza de una clarisa: doña María Dávila y el arte funerario", El viaje de San Francisco por la Península Ibérica y su legado, Asociación de Estudios Franciscanos, 2010, pp. 253-285; y María Dávila, una dama de la Reina Isabel: promoción artística y devoción, Ávila, 2010.

19 Por ejemplo, en la iglesia del desaparecido Monasterio de Espeja de San Marcelino en Soria los Condes de Castrillo construyeron un palacete adosado a la capilla mayor de la iglesia. Podían asistir a los oficios divinos desde dos balcones dorados a un lado y otro del presbiterio: "A un lado y otro del presbiterio hay dos balcones dorados por donde pueden oír misa desde su cuarto los Condes de Castrillo, por estar contiguo a dicha capilla un regular palacio..." Cita tomada de J. LOPERRÁEZ CORVALÁN, "Descripción histórica del obispado de Osma”. Recogido en Historia de la Villa de Espeja y sus cosas notables, 1788, en www. webdejavier.espejadesanmarcelino.orginicio.htm.doc.

20 P. FERNÁNDEZ MONJARAZ, Panegírica descripción del milagroso aparecimiento de Nuestra Señora de Nieva: histórica fundación de su real Villa, Segovia, 1669, cap. XIII, p. 67. Citado por A. SÁNCHEZ SIERRA, op. cit., 1992, p. 128.

21 Juan II, rey de Navarra, era hijo de Leonor de Alburquerque y Fernando I, hijo a su vez de Juan I y Leonor de Aragón y, por tanto, hermano de Enrique III. A. DE APRÁIZ estableció una relación entre la Virgen de Nieva y su advocación en Navarra. Vid. "La Virgen de Nieva y su relación con Navarra", Estudios Segovianos, t. 2, Segovia, 1949. 
Esta disposición arquitectónica de tribuna o balcón con vistas al altar fue habitual en muchos de los templos patrocinados por monarcas o personas de la nobleza; la posibilidad de participar en las ceremonias litúrgicas desde un lugar privilegiado se convirtió en un signo de distinción que quedaría inmortalizado en los monumentos funerarios de orantes tan frecuentes en la decimoquinta centuria. La representación del difunto en actitud orante, dirigiendo su mirada hacia el altar, arrodillado frente a un atril sobre el que se dispone un libro abierto, y situado en una zona próxima al altar se convirtió en una modalidad de sepulcro de gran fortuna en el siglo XV. Se asemejaría al balcón o tribuna que

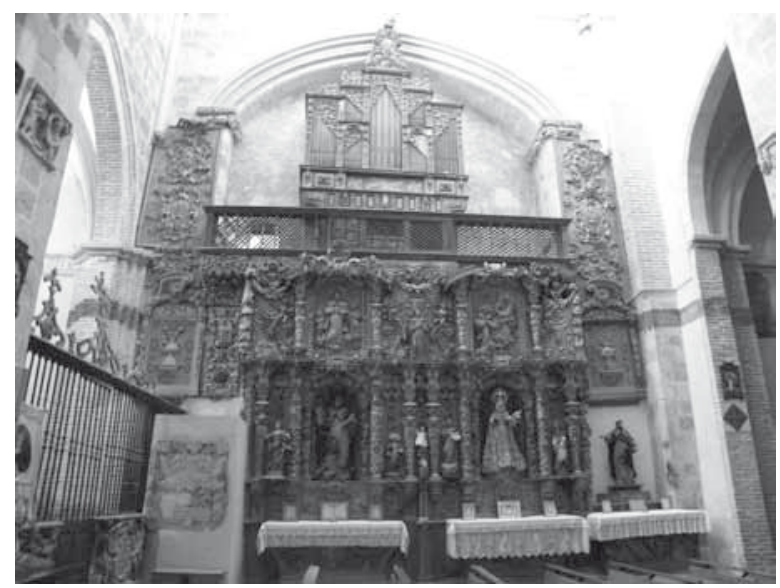

Fig. 2. Convento de Santa María la Real de Nieva, interior de la iglesia, tribuna. comunicaba las estancias palaciegas con el altar, una tipología anclada en el tiempo y de la que cada vez se van conociendo más ejemplos. Esta tipología sepulcral permitía al difunto-donante asistir eternamente a las ceremonias religiosas desde su estancia privada, como había hecho en vida.

El origen de esta fórmula, en la que se representa al difunto como orante, acompañado de dos pajes en el interior de un nicho de gran profundidad y dirigido hacia el altar como si de una

tribuna se tratara, fue una creación original de Egas Cueman, como se ve en el sepulcro de Alfonso de Velasco y su esposa en Guadalupe, fechado en 1467. Este modelo se repetirá en el sepulcro de los Pacheco en Belmonte, en el del Conde de Buendía en Dueñas o en el ejemplo más conocido del infante Don Alfonso en la Cartuja de Miraflores. De este modo, se ofrece una imagen del difunto en vida, realizando una actividad piadosa como es la lectura del libro de horas pero remarcando también su estatus social que repercutirá en su fama posterior.

La presencia de un palacio real en el Convento de Santa María la Real de Nieva nos permite afirmar que fue un centro importante dentro de la Orden de Santo Domingo y con una vinculación significativa con la Corona. Sus muros albergaron un palacio destinado a los miembros de condición real y la distribución de sus estancias demuestra que siguió el modelo habitual de otros conventos, monasterios y catedrales españolas en las que los espacios regios formaban una unidad con los eminentemente religiosos. 


\section{La reina Catalina de Lancaster, el programa iconográfico de la portada y la imagen real}

La condición de la reina Catalina como patrocinadora del convento confirma el protagonismo femenino en la esfera artística durante los siglos finales de la Edad Media $^{22}$. La relación de la reina con la fundación segoviana no se limitó únicamente al aspecto económico sino que tenemos motivos para pensar que pudo influir en la concepción del programa iconográfico desplegado en la portada de la iglesia.

La puerta que concentra un mayor número de imágenes en la Iglesia de Santa María la Real de Nieva se abre en la zona norte, integrándose en la cabecera del templo. Esta peculiar ubicación obedece a razones prácticas ya que en la fachada sur se abría el acceso al claustro y a las estancias palaciegas y la única portada anterior que existía en el costado norte acabó formando parte del interior del edificio cuando se añadieron una serie de capillas, convirtiéndose en el acceso a una de ellas, la dedicada a "las Cinco Llagas". Esta distribución obligó a la apertura de una nueva portada al exterior y el único espacio sobrante se situaba en la propia cabecera del templo, ya que a los pies se situaba la Puerta del Perdón. De este modo, se crea una estructura insólita en la que la portada de mayor despliegue artístico se proyecta no hacia la plaza situada en el lado sur sino en un ámbito más íntimo y de menor repercusión en el campo urbanístico actual; no sabemos si tuvo la misma distribución en el siglo XV. La fachada sur cumplía una función civil y representativa puesto que allí estaba la entrada a las estancias reales. Por tanto, la nueva organización de la iglesia y el establecimiento de una residencia regia en el conjunto conventual desplazaban la ubicación de la portada principal al lado norte integrada en el cuerpo de la cabecera.

La portada está realizada en sillería regular y se dispone delante del cuerpo de la cabecera en un bloque autónomo. Sigue el tipo común en la época: enmarcada por dos potentes contrafuertes cajeados, que en su día albergaron sendas parejas de esculturas, como dan cuenta las ménsulas y doseletes que aún se conservan. La portada propiamente dicha está cobijada por seis arquivoltas que dibujan un acceso apuntado. Remata todo el conjunto en un arco conopial que presenta en su vértice un símbolo mariano tradicional, el jarrón con azucenas, ilustrando la advocación del templo dedicado a Santa María de Nieva.

Las arquivoltas acogen un importante conjunto de temas propios del gótico clásico, como son la resurrección de los muertos, santos y santas mártires y ángeles. Descansan en una serie de capiteles corridos que presentan con todo detalle la

22 La bibliografía es inmensa y difícilmente abarcable en una nota a pie de página. Citaremos el estudio de F. PEREDA sobre Da Mencía de Mendoza, esposa del Condestable de Castilla, con bibliografía general sobre el patronato femenino en esta época: "Mencía de Mendoza (+ 1500). Mujer del I Condestable de Castilla: el significado del patronazgo femenino en la Castilla del S. XV”, B. ALONSO, M.C. DE CARLOS y F. PEREDA, Patronos y coleccionistas. Los Condestables de Castilla y el arte (siglos XV-XVII), Valladolid, 2005, pp. 9-119. 
historia de la Pasión de Jesucristo, desde la Última Cena hasta la Resurrección y el Noli me Tangere. En la parte tocante a las jambas, los 12 pedestales y doseles, repartidos en grupos de 6 a un lado y otro, son los únicos restos de un conjunto que debió de presentar las figuras de los apóstoles, como es común a otras portadas. Finalmente, consta de un dintel y un tímpano que alberga una serie de figuras hoy descabezadas componiendo un tema habitual en algunas catedrales españolas, el de Cristo mostrando sus heridas acompañado por las figuras de la Virgen y San Juan como intercesores.

Se observa, pues, la intención de englobar el ciclo completo de la Pasión y el Juicio Final, es decir, la Redención y Salvación como un unicum, agrupando, por tanto, los temas principales del gótico clásico, un detalle que nos habla del carácter arcaico que define todo el conjunto de Santa María de Nieva. Se trataría de un ejemplar tardío que agrupa temas canónicos siguiendo una formulación propia de una cronología anterior. Un hecho común en empresas alejadas de los importantes centros artísticos, a las que podríamos calificar de periféricas, y llevadas a cabo en fechas posteriores. El resultado es una obra de gran originalidad que responde a modelos anteriores pero adaptado, a su vez, a las circunstancias especiales de cada caso, dando lugar a conjuntos en los que se sintetizan los logros de generaciones precedentes.

Puesto que el tema propuesto en este trabajo no se centra en el análisis minucioso de la portada, nos fijaremos en aquellos aspectos que tengan relación con la personalidad de la reina y en su posible condición de mentora iconográfica.

El advenimiento del Juicio Final, en el que se juzgaban las buenas y las malas obras de toda una vida, ejerció una gran presión en las conciencias de la sociedad medieval provocando, incluso, sentimientos de pánico. A ello contribuían los discursos de los predicadores que tenían como principal objetivo sugestionar a los fieles y prepararlos moralmente para los sucesos que se avecinaban. Así, predicadores ilustres, como San Vicente Ferrer recorrieron amplios territorios de la geografía peninsular explicando los tres advenimientos de Jesucristo y el Juicio Final, recreándose especialmente en las penas del infierno que sufrirán aquéllos que se obcequen en el pecado ${ }^{23}$. La reacción provocada en las masas es descrita por sus primeros biógrafos y contemporáneos pero podemos hacernos una idea a partir del siguiente texto de Huizinga:

${ }^{23}$ Sobre la predicación de San Vicente Ferrer existe una nutrida bibliografía de la que recogemos los siguientes estudios, J.M. MILLÁS VALLICROSA, "San Vicente Ferrer y el antisemitismo", Sefarad, X (1950), pp. 182-185; J.M. DE GARGANTA y V. FORCADA, Biografía y escritos de San Vicente Ferrer, Madrid, 1956; J.M. MILLÁS VALLICROSA, "En torno a la predicación judaica de San Vicente Ferrer", Boletín de la Real Academia de la Historia, CXLII (1958), pp. 189-199; P.M. CÁTEDRA, Los sermones atribuidos a Pedro Marín. Van añadidas algunas noticias sobre la predicación castellana de San Vicente Ferrer, Salamanca, 1990, y Sermón, sociedad y literatura en la Edad Media. San Vicente Ferrer en Castilla (1411-1412), Salamanca, 1994. 
"Allí donde predica es necesario un valladar de madera para protegerle con su séquito de la presión de la muchedumbre...y cuando habla del Juicio Final y de las penas del infierno, o de los dolores del Salvador, prorrumpe siempre, tanto él como sus oyentes, en tan gran llanto, que necesitaba permanecer en silencio mucho tiempo hasta que el llanto se calmara" 24 .

Muchos de estos discursos públicos tenían lugar en los atrios de iglesias y catedrales, en los que la escultura monumental de las portadas visualizaba el contenido de las prédicas, y muchas de ellas influyeron en la concepción iconográfica de retablos y portadas con temática escatológica.

Tenemos constancia de una predicación de San Vicente Ferrer en Santa María de Nieva en 1402, es decir, cuando aún se estaba construyendo el convento. Esta visita tuvo una respuesta popular multitudinaria y de ello dan cuenta los cronistas:

"Añade veneración al Santuario, el aver predicado en el año de mil quatrocientos e dos, San Vicente Ferrer, circunstancia que oy se estima con singular aplauso: y el púlpito es tan venerado de los religiosos sus hermanos que ha avido quien para predicar en él se descalçó" 25 .

Teniendo en cuenta que unos años después de esta visita se emprendieron las obras en la portada, no debemos pasar por alto la posible influencia de los sermones de San Vicente en la configuración iconográfica de la portada, en la que además existe un antijudaísmo manifiesto en algunas de las escenas de la Pasión de

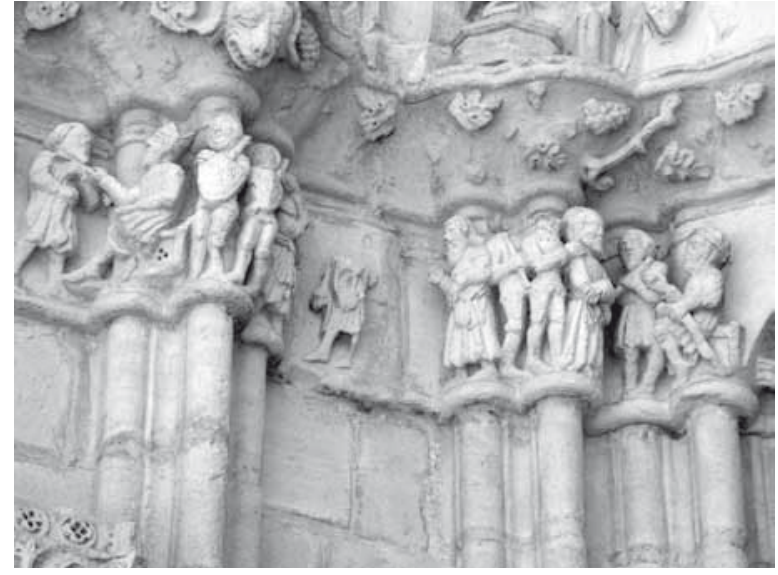

Fig. 3. Convento de Santa María la Real de Nieva, portada de la iglesia, detalle de los capiteles.
Cristo representadas en los capiteles $^{26}$. Los momentos correspondientes a la Pasión, en los que se pone de manifiesto el sufrimiento de Cristo, están protagonizados por personajes tocados con el gorro cónico que distingue a los judíos. Tal es el caso del Prendimiento, en el que los soldados y guardias que detienen a Jesús portan el característico gorro puntiagudo que distingue a los judíos, señalándolos de este modo como los responsables de este hecho (fig. 3). Se utiliza, pues, un len-

24 J. HUIZINGA, El Otoño de la Edad Media, Madrid, 1984, p. 18.

25 Texto escrito por Fernández Monjaraz. Recogido por A. SÁNCHEZ SIERRA, op. cit., 1992, p. 108.

${ }^{26}$ La representación de las escenas en un friso continuo que forma los distintos capiteles sigue el modelo de ejemplos anteriores, como es el caso de la Catedral de Chartres, que ratifica el carácter arcaico de la fundación segoviana. 
guaje subliminal de carácter antijudío en el que quizá debamos ver un influjo de las prédicas vicentinas en Santa María y, como consecuencia, del ordenamiento de Valladolid dictado por la reina Catalina de Lancaster en 1412 sobre el modo en que tenían que vestir los judíos y musulmanes para que los cristianos pudieran diferenciarlos ${ }^{27}$. Si bien, aunque el cumplimiento de estas normas fue limitado, como demuestran las constantes quejas emitidas desde la Iglesia, el objetivo no era transmitir una imagen fiel a la realidad en las representaciones artísticas sino servirse de un código iconográfico, ya establecido, que era comprendido por todas las facciones de la sociedad y que permitía percibir de forma nítida el papel desempeñado por los judíos en los momentos más dramáticos del relato evangélico ${ }^{28}$.

Mediante los rasgos estereotipados, que coinciden con una nariz ganchuda y el tipo de gorro terminado en punta, se les presenta como la encarnación del mal y los responsables directos de la muerte de Jesucristo. De este modo, no quedaban dudas sobre la intervención directa en la Pasión y se hacía hincapié sobre la crueldad innata con que les caracterizaban, incentivando el odio de la población cristiana hacia ellos ${ }^{29}$. Por otro lado, se otorga un papel preponderante a la escena misma de la traición, cuando Judas se presenta ante el Sumo Sacerdote. La gesticulación de ambos es lo esencial de la escena. La autoridad posa su mano derecha sobre la izquierda del otro personaje. Este gesto es bien conocido en la iconografía y denota protección $^{30}$. El Sumo Sacerdote está protegiendo a Judas y, por tanto, confirmando el pacto que habían alcanzado.

Otras figuras caracterizadas como judíos, con gorro terminado en punta, cierran la escena de la Flagelación. Aunque no poseen ningún elemento que los distinga ${ }^{31}$,

27 “Otrosy, que ningunos ni algunos judíos de mis regnos e sennorios, de oy en dies días en adelante, non trayan capirotes con chinas luengas, salvo que sean las chinas cortas, fasta un palmo, fechas a manera de enbudo, de cuerno cosydas en derredor hasta la punta...”. Biblioteca del Monasterio de San Lorenzo de El Escorial, Ms. Z-I-6 (siglo XV), ff. 139v-142r. Recogido en A. ECHEVARRÍA ARSUAGA, op. cit., 2002 , p. 153.

28 J. MOLINA I FIGUERAS, "La imagen y su contexto. Perfiles de la iconografía antijudía en la España Medieval", Els jueus a la Girona medieval (XII ciclo de conferencias Girona a l'Abast), Girona, 2008, p. 64.

${ }^{29}$ La lista de estudios sobre la imagen del judío es cada vez más amplia. Para una aproximación general al tema, J.M. MONSALVO, "Mentalidad antijudía en la Castilla medieval", Xudeus e Conversos na Historia I: Mentalidades e Cultura (Ribadavia 14-17 octubre 1991), Orense, 1994, pp. 21-84. E. GARCÍA MONTENEGRO, "La imagen del judío en la España medieval”, Espacio, Tiempo y Forma, Historia Medieval, 11 (1998), pp. 11-38; M. CAMILLE, El ídolo gótico. Ideología y creación de imágenes en el arte medieval, Madrid, 2000, en concreto pp. 182-197; J. MOLINA I FIGUERAS, "Las imágenes del judío en la España Medieval", Memoria de Sefarad, Toledo, 2002, pp. 373-385; J. VALDEÓN BARUQUE, Judíos y conversos en la Castilla medieval, Valladolid, 2004, y El chivo expiatorio: judios, revueltas y vida cotidiana en la Edad Media, Valladolid, 2004; J. MOLINA I FIGUERAS, op. cit., 2007, pp. 34-85.

30 Por poner un ejemplo, lo vemos en La traición de Judas de Giotto en la Capilla de la Arena de Padua. M. BARASCH, Giotto y el lenguaje del gesto, Madrid, 1999, pp. 163-176.

31 El personaje cubierto con capucha sostiene una especie de báculo que quizá indique su condición de autoridad de la Ley Mosaica. Está demostrado que las autoridades de otras religiones eran representadas con atributos de los obispos cristianos, como la mitra, para acercar el contenido a todo tipo de público. R. MELLINKOFF, "Christian and Jewish mitras: a paradox", Florilegium in honorem Carl Nordenfalk, Esto- 
en otros ejemplos del mismo tema, junto a los verdugos, se incluyen las figuras de Anás y Caifás con toda una declaración de intenciones de resaltar el protagonismo de los judíos en los episodios de la Pasión ${ }^{32}$.

El influjo de las prédicas del fraile dominico sobre la iconografía bajomedieval ha sido señalado para varias obras del entorno catalano-aragonés ${ }^{33}$. El predominio del tema de la inminente venida del Anticristo y el Juicio Final en sus discursos públicos causó un gran impacto en la conciencia de las masas que se acrecentaba al contemplar las imágenes esculpidas y pintadas.

Fray Vicente tuvo, además, un estrecho contacto con $\mathrm{D}^{\mathrm{a}}$ Catalina de Lancaster, la fundadora del convento, y se sabe que ejerció una gran influencia religiosa sobre la reina hasta el punto de que se cree que el ordenamiento que dictó sobre judíos y musulmanes, publicado en Valladolid en 1412, se debió al impacto que causaron los sermones del fraile dominico acerca de la necesidad de apartar las minorías religiosas en todas las ciudades del reino para evitar el contacto con los cristia$\operatorname{nos}^{34}$. Las ordenanzas compilan toda una serie de normas sobre las relaciones entre miembros de las distintas confesiones religiosas, el lugar de residencia o cuestiones sobre la vestimenta que debían llevar los musulmanes y judíos con el fin de que se les identificara.

La portada de Santa María de Nieva reúne el ciclo de la Pasión y el Juicio Final, formando un mensaje único y coherente en el que el camino hacia la Salvación se inicia con el Sacrificio de Cristo, poniendo un énfasis especial en distinguir a los judíos y señalarlos como los responsables más directos. La situación social que se vivía en Castilla en ese momento, la responsabilidad directa de la reina en la nueva coexistencia entre cristianos, judíos y musulmanes y su condición de patrona del convento quizá se vea reflejada en las distintas imágenes de la portada. Aunque la reina murió en 1418 y no pudo ver el resultado, sí es probable que interviniera en el planteamiento iconográfico de la misma. No es de extrañar, puesto que la extensión de prácticas devocionales cristocentristas basadas en una meditación sobre el sufrimiento de Cristo en los diferentes episodios de la Pasión fue frecuente, sobre todo, a finales de la Edad Media y en entornos femeninos de alta condición social ${ }^{35}$. Por otro lado, es en este contexto de devoción a la Pasión de Cristo donde se constata una mayor presencia del judío en el desarrollo de

colmo, 1987, pp. 145-158; y J. YARZA, "Del alfaquí sabio A los seudo-obispos: una particularidad iconográfica gótica”, Sharq Al-Andalus, 10-11 (1993-1994), pp. 749-776.

32 Vid. la escena de la Flagelación del Libro de Horas de María de Navarra conservado en la Biblioteca Marciana de Venecia. Citado por J. MOLINA I FIGUERAS, op. cit., 2008, p. 57.

33 Véanse los comentarios al respecto en la Tesis Doctoral de P. RODRÍGUEZ BARRAL, La imagen de la justicia divina. La retribución del comportamiento humano en el más allá en el arte medieval de la Corona de Aragón, tesis doctoral inédita, Universidad Autónoma de Barcelona, Barcelona, 2003.

34 A. ECHEVARRÍA ARSUAGA, op. cit., 2002, p. 150.

35 J. MOLINA I FIGUERAS, op. cit., 2008, p. 61. 
los acontecimientos. En este sentido, Joan Molina ha sugerido la posibilidad de que las mujeres de alta alcurnia tuvieran un alto grado de responsabilidad en la promoción de imágenes en las que el judío es personaje principal en la Pasión de Cristo $^{36}$.

Podemos decir que nos encontramos ante uno de los programas pasionales más completos en el que se han recogido, con todo detalle, los distintos episodios que conforman el capítulo de la Pasión y Resurrección. Utilizando los elementos arquitectónicos que conforman la portada, los artistas han sabido adaptar cada una de las escenas al espacio disponible. Por otro lado, la sucesión de las respectivas figuras en un registro continuo, en la parte que debía corresponder a los capiteles de las jambas, supone una solución de gran originalidad que permite desarrollar un ciclo más completo que si se hubiera optado por el tímpano.

El carácter marcadamente narrativo de las distintas escenas se halla en consonancia con la vocación pastoral de las órdenes mendicantes y las convierte en un instrumento didáctico perfecto dirigido probablemente a los fieles que, a juzgar por el emplazamiento de la iglesia y la ampliación del s. XIV, accederían al templo por esta puerta.

Atendiendo al lugar donde se expone este ciclo de imágenes, en la portada de la iglesia, y al público que lo iba a percibir, podemos decir que pudo haber una intención antijudía en su programación, destinada a fomentar un sentimiento de rechazo hacia aquéllos que calificaban de deicidas.

La ascendencia real sobre la fundación no sólo se refleja en la advocación sino que imágenes y escudos se suceden en varias zonas de la iglesia y el claustro. El tímpano de la portada está ocupado por la figura de Cristo en su faceta de Juez. En su advenimiento se representa en toda su majestad, sentado sobre un trono y ataviado con un manto que, aunque la erosión pétrea no nos permite asegurarlo, probablemente dejaba al descubierto el pecho y los pies para mostrar sus heridas al igual que en las manos, hoy perdidas. Es el Cristo que preside el Juicio Final. Enviados por Él, los ángeles llaman a los muertos con sus trompetas y éstos acuden para ser juzgados. La resurrección de los muertos se ha desplazado a la arquivolta externa, de manera que el tímpano y las arquivoltas forman una unidad iconográfica que acoge el tema del Juicio Final.

A ambos lados de Cristo se sitúan las figuras de la Virgen y San Juan. No están sentados sino de pie, aunque ligeramente inclinados y en actitud suplicante, como ocurre por ejemplo en la portada norte de la Catedral de Burgos. Se han perdido las cabezas y las manos pero la posición de sus brazos sugiere que se unían en oración. La figura de la Virgen intercesora en las escenas de la Parusía y de Juicio Final se acompaña de San Juan y ambos pasan a ser los primeros abogados

\footnotetext{
36 Ibidem.
} 


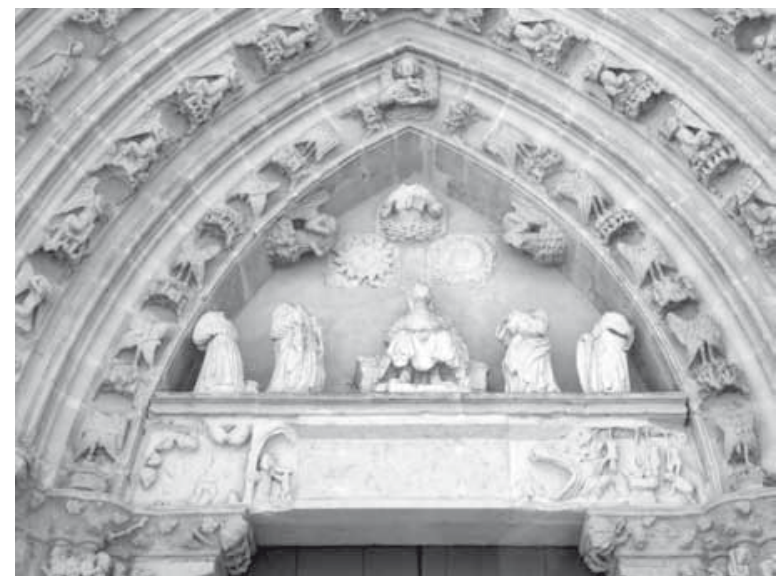

Fig. 4. Convento de Santa María la Real de Nieva, portada de la iglesia, tímpano. de la humanidad ante el Juez Supremo. Pero, en este caso, no están solos. Tras ellos, dos figuras, también descabezadas, se presentan ante Cristo (fig. 4). Ocupan los dos extremos del tímpano y tienen un tamaño similar a las figuras de la Virgen y San Juan. Los cuatro personajes llevan pesados ropajes de abundantes pliegues tratados con un gran naturalismo. El situado a la izquierda del espectador parece estar arrodillado sobre un cojín, con una actitud pietista propia de las mujeres en la Edad Media. Además, la propia indumentaria, consistente en un vestido ceñido a la altura de la cintura, parece apoyar la hipótesis de que se trata de una fémina. Por el contrario, la figura situada en el lado opuesto está de pie y viste túnica y manto.

La condición real de la iglesia de Santa María de Nieva se pone de manifiesto no sólo en la advocación -Santa María la Real de Nieva- sino en la propia documentación, cargada de alusiones a la protección económica y moral que los monarcas Enrique III y Catalina de Lancaster, en especial la reina, dispensaron a la fundación. De este modo, podemos pensar en una posible inclusión de la imagen de los reyes en la portada. La propia iconografía refrenda el patronato real situando las efigies de los fundadores en el lugar más importante y visible de la portada. Así, la vinculación de los monarcas con una empresa religiosa repercute en su prestigio personal, a la vez que la propia fundación es prestigiada. Las alusiones a los diferentes monarcas que prestaron su colaboración con esta fundación religiosa no quedaron ahí. En esta misma fachada son representados sus escudos y rostros que amueblan el arranque de unas ménsulas. La imaginería no sólo perpetúa el recuerdo de los reyes en la memoria de los vivos como responsables de la fundación, sino que se representan ante la divinidad en el momento del Juicio, como si de su juicio individual se tratase, contando con el apoyo de la Virgen y San Juan como intercesores. En este sentido, a partir del s. XII el individuo cobra cada vez más importancia en el pensamiento teológico reflejándose en la idea del juicio particular que recibirá cada uno. Pero, según Alberto Tenenti, es a lo largo del s. XV cuando en la iconografía del Juicio Final se observa una decantación de lo colectivo hacia lo individual. Esto se hace visible en algunos detalles como la inclusión de algunos elementos que particularizan a los resucitados o bien la presencia del promotor de la obra que, al tiempo que ofrece una imagen devocional de sí mismo, apuesta por 


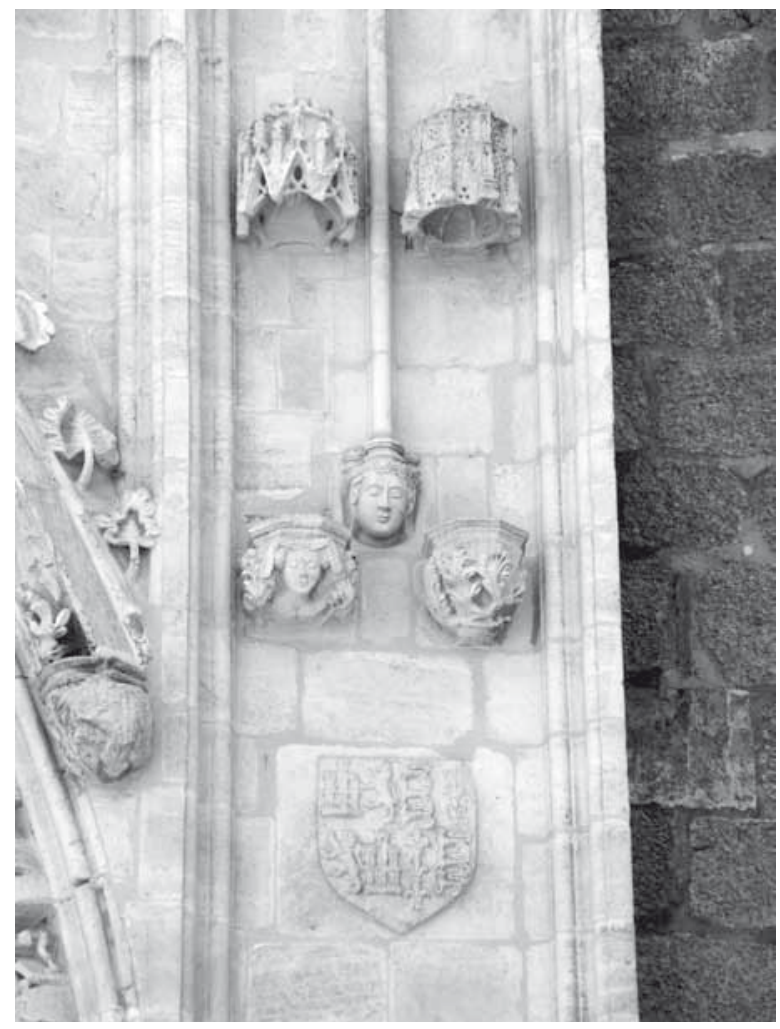

Fig. 5. Convento de Santa María la Real de Nieva, exterior, escudo de Catalina de Lancaster. cado con velo y coronado con flores. Su emplazamiento por encima del símbolo heráldico puede ser un indicio sobre la identidad del personaje, quizás la propia reina Catalina. Dejando a un lado la fidelidad de los rasgos, improbable dada la época temprana en que nos encontramos, lo cierto es que la presencia de los escudos reales y los rostros de los monarcas, también representados junto a los personajes sagrados en el tímpano, informan del patrocinio real de la fundación y refuerzan el prestigio social de los reyes a la vez que su recuerdo se inmortaliza en la memoria de los vivos. No obstante, tanto las obras de la portada como las del claustro ${ }^{38}$, donde también aparecen los emblemas reales, se realizan durante el reinado del

37 A. TENENTI, “L'attesa del giudizio individuale nell'iconografia del Quattrocento", L'attesa de l'età nuova nella spiritualità della fine del Medioevo, III Convengo del Centro di Studi sulla Spiritualità Medievale, Todi, 1960, pp. 173-193. Citado por P. RODRÍGUEZ BARRAL, op. cit., 2003, p. 277.

38 Debido a las limitaciones de espacio, nos resulta imposible abordar el estudio del claustro en el presente artículo a pesar de su indudable interés. 
hijo de Enrique III, Juan II, por lo tanto debemos entenderlas como un recuerdo y homenaje a sus progenitores y un indicativo de su condición de promotores.

En definitiva, la portada de Santa María la Real de Nieva constituye una fuente de transmisión de conocimientos teológicos relativos a la Pasión de Cristo y su Segunda Venida destinados a adoctrinar a los fieles e indicarles el camino a seguir para conseguir la redención y las consecuencias derivadas de su comportamiento. Si tenemos en cuenta que la ampliación de la cabecera se inició en 1414 y se prolongó hasta 1432, fecha en que se terminaron las capillas del crucero según reza la inscripción en uno de los pilares del mismo, podemos considerar esta última fecha como el punto de partida de las obras de la portada. El protagonismo concedido al tema pasional y escatológico y el peso que se otorga a los judíos como causantes del sufrimiento de Cristo han de verse en relación con la mentalidad escatológica de la sociedad medieval, en la que tuvieron un gran peso las predicaciones de San Vicente Ferrer por una gran parte de la geografía peninsular. La población estaba habituada a este tipo de discursos que podían visualizar en las representaciones artísticas de las iglesias.

Por otro lado, al insertar los símbolos heráldicos, e incluso las imágenes, de los reyes Enrique III y Catalina de Lancaster no se desaprovecha la ocasión para homenajear a los fundadores de la empresa, a pesar de que en ese momento ya reinaba su hijo Juan II. Por otra parte, como hemos señalado, la documentación, la epigrafía y la iconografía, nos permiten señalar una mayor responsabilidad de la reina en la obra y el diseño de los programas. 